\title{
Air Reconnaissance: Recent Results, 4
}

PLATE XXIX

The photographs (PL. xxrx) show an unexpectedly intricate maze of crop marks lying towards the west corner of the parish of Great Shelford and barely 4 miles south of the centre of Cambridge. No traces appear on the surface but a walk over the fields yielded one piece of Roman pottery. The ground here, which is almost level and at a height of about $50 \mathrm{ft}$. O.D., is bounded to the south by a low scarp, where the surface drops some $6 \mathrm{ft}$. to the floodplain of the river Cam or Granta. Northeastwards the ground slopes very gently up to a low ridge the crest of which lies parallel to, and at $300 \mathrm{yd}$. distance to south-west of the main road from Trumpington to Great Shelford (A.130). Sections exposed in drainage ditches show below the soil at least 6 or $7 \mathrm{ft}$. of gravel overlying chalk marl.

The crop marks reveal the positions of ditches, pits and post-holes of a series of agricultural settlements, and their fields. The enclosures have been replanned time and again as one settlement has succeeded another, the occupation perhaps lasting, on the analogy of sites elsewhere, through much of the late Iron Age and Roman periods. The photographs were taken on 17 th June 1960 , when the land was under cereal crop. The sketch-plan (FIG. I) has been prepared from vertical 'cover' taken only 3 days later when all the essential details were recorded, though without the vivid contrast in tones seen in the photograph (PL. XXIXa) as the colours had faded in this short interval, and the striking colour differences had been lost.

The description of the complex may begin at the east, where lines of straight ditch define rectangular plots or fields ( $T L 448526$ ). In the main group of crop marks, four or more different systems of overlapping enclosures may be distinguished. At one stage an accommodation road flanked by ditches led to the site from the north-east. Beside one of these ditches and parallel to it is a line of closely spaced pits, of the kind variously described as 'palisade lines' or 'pit alignments'. The conclusion that this feature is part of the complex and thus of Iron Age or Roman date is difficult to resist.* The gaps in some of the ditches marking entrances to the enclosures will be noted. They are matched by details of the plan of the Belgic settlements at Eaton Socon [I], in Huntingdonshire, and Thorpe Achurch, in Northamptonshire [2]. The full sequence of the remains could hardly be established without excavation, but the clearly marked, broad ditch lying eastwest about the centre of the complex may be recognized from its relationship to other elements in the plan, as a relatively late feature, perhaps a recutting of an earlier ditch. To south of it a small circular ditch broken by a gap may be the foundation trench of a round hut, apparently rebuilt. Another circular ditch lies within the irregularly shaped oval enclosure to north-west of this, and there seems to be yet another, overlain by ditches of three different phases, near the dark triangle of crop extending from the edge of the field. It would be interesting to know whether some of the small holes visible here held posts of a timber building. The dark triangle is probably due to an old kink in the river scarp which has been straightened when the fields were laid out: long continued ploughing has filled the hollow with surface soil which promotes a dark growth of crop. The clearly marked subrectangular enclosure further to the north-west also contains a small circular ditch, interrupted by a gap. The circle, seen as a very slender crop mark, was perhaps the foundation trench of a hut.

At the angle of the field where the river scarp changes direction (PL. $\mathrm{xxIx} b$ ), a remarkable group of closely set pits upwards of $15^{\circ}$ in number is visible, forming a semi-circle about $230 \mathrm{ft}$. in diameter (TL 444525). Occasional pits may be distinguished elsewhere in the field though a number of the irregularly shaped random marks may be hollows from which tree-stumps have anciently been uprooted. However, such closely clustered pits are

* It would thus compare with pit alignments at Tallington in the Welland valley for which a similar date is postulated on the evidence of excavation, as Mr. G. Simpson kindly informs me. 


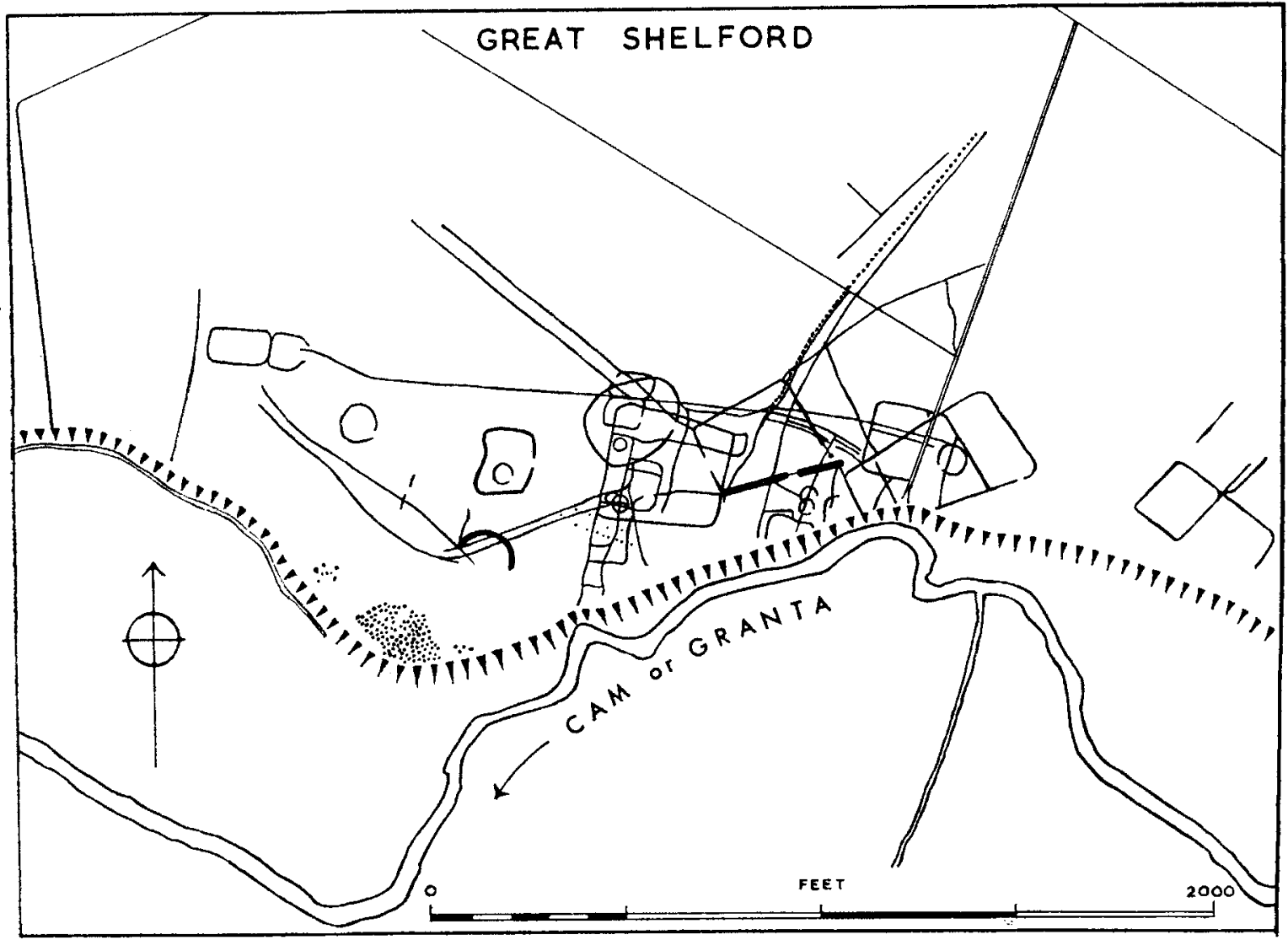

Fig. I. Plan of crop marks at Great Shelford. In drawing this plan the evidence of all available vertical and oblique photographs has been taken into account. The shapes of the enclosures differ slightly from the rendering in PL. XXIXa owing to distortion induced by the obliquity.

sufficiently unusual [3] to invite speculation. With gravel such as this, and a water-table lying 5 to $6 \mathrm{ft}$. below the surface, storage pits can hardly be in question. If they are rubbish pits, why do they lie so far from the rest of the remains, or are there many other structures, hut foundations and the like, that have caused too slight disturbances in the soil to promote any growth differences in the crops?

It should not be supposed that this was the only settlement of its kind hereabouts. An even more extensive group of crop marks has been recorded across the stream in Little Shelford parish, and others may well have existed on the right bank. However, a considerable tract of land extending for a mile between Hauxton and Trumpington was in the Igth century worked over for coprolites, extracted in opencast pits dug down to the Cambridge Greensand, so that any ancient sites there will have been destroyed. Beyond this again, north of the Cambridge to Bedford railway, another group
PLATE XXIX (a)

Crop marks, Great Shelford, Cambridgeshire (TL 447526). Oblique photograph.
PLATE XXIX $(b)$

Crop marks, Great Shelford (TL 444525). Oblique photograph.

[Copyright reserved, University of Cambridge. 


\section{NOTES AND NEWS}

of enclosures has been identified in the grounds of the Plant Breeding Institute, Trumpington (TL 435545).

The complexity of the remains at Great Shelford could be matched many times over amongst air photographs of settlement sites on valley gravels taken in recent years. Major Allen's photographs of Stanton Harcourt [4] in the Thames valley come to mind, but the Ouse, Nene, Welland, Warwickshire Avon and Trent all yield examples. The range in time and the agricultural economy of the settlements can be established only by excavation, which, at Great Shelford, would be no light task in view of the many different overlapping and intersecting elements involved.

\section{NOTES}

[1] G. F. Tebbutt, Proc, Camb. Antiq. Soc., 50, I $957,75-84$, pl. $\mathrm{v}$.

[2] J. K. St Joseph, Air Force Dept. Soc. F., 5, I964, pl. D.

[3] Cf. Little Woodbury, Wiltshire. O. G. S. Crawford, ANTiQuity, 1929, 452-5, pl. I facing p. 385 , and for the excavation of the site, G. Bersu, Proc. Prehist. Soc., 6, 1940, 30-I I I and especially plates II-III.
[4] O. G. S. Crawford, Luftbild und Vorgeschichte (r 938), plate on p. $3^{8}$ : for a plan of crop marks at Stanton Harcourt, see W. F. Grimes, Excavations on Defence Sites 1939-45, (I960) fig. 57. Cf. also the crop marks by Maxey Church, and near Helpston and Barholm, A Matter of Time (RCHM, I96o), figs. 6, 9-10.

Corrigendum. In 'Air Reconnaissance: Recent Results, 3', ANTIQUITY, 1965,63 , right-hand column, the grid-reference of the seven small circles at Stoke-by-Nayland should read TL 984349 .

\section{A Spirally Decorated Object from Garboldisham}

PLATE XXXII

Mr A.R. Edwardson, Curator of the Moyses Hall Museum, Bury St Edmunds, Suffolk, sends us this note on a spirally decorated antler object found in Norfolk in 1964 .

Road and bridge repairs at the spot where the road from Hopton in Suffolk crosses the river Little Ouse on the way to the village of Garboldisham in Norfolk (TM 003801 ) necessitated the construction of a coffer dam on the north bank of the river. At a depth of $5 \mathrm{ft}$. beneath the river bed, an exceptional implement was recovered, associated with animal bones. The implement, dark brown in colour, was of polished red deer antler and decorated on one side with an incised spiral design, which was carried over the shoulder of the implement to be repeated twice on the other side. The implement had been bored by means of a hole $20 \mathrm{~mm}$. in

[I] See S. Piggott, The Neolithic Cultures of the British Isles, 1954 (esp. pls. vir and XIr; fig. 33, 5a); G. E. Daniel, The Megalith Builders of Western Europe, (1958), pl. virr; S. Piggott and G. E. Daniel, diameter and $65 \mathrm{~mm}$. long to permit of hafting, and the measurements give a length of $102 \mathrm{~mm}$., width of $76 \mathrm{~mm}$. and thickness of $50 \mathrm{~mm}$.; the weight is $12 \mathrm{oz}$. Although apparently intended as a hammer or mallet the end shows no clear sign of wear, and it would seem therefore to have been a cult object.

The object belongs to Mr D. G. Lawrence of Moat House, Hinderclay, Suffolk, by whose permission it is here published. On stylistic grounds this object may be compared with the spirals in mural megalithic art at New Grange and elsewhere, with the sherd from Skara Brae, and the decorated stone balls from Scotland. It could then perhaps be dated to between 2500 and I500 B.C. [I].

Mr Lawrence has generously agreed to deposit this object on loan to the Museum.

A Picture Book of Ancient British Art (195 I), pl. I8; S. P. ORiordáin, Antiquities of the Irish Countryside, (r953), pls. 58,62 . 